\title{
Synthesis, Spectroscopic, and Antimicrobial Studies on Bivalent Zinc and Mercury Complexes of 2-Formylpyridine Thiosemicarbazone
}

\author{
Sulekh Chandra, ${ }^{1}$ Shikha Parmar, ${ }^{2}$ and Yatendra Kumar ${ }^{2}$ \\ ${ }^{1}$ Department of Chemistry, Zakir Husain College, University of Delhi, Jawaharlal Nehru Marg, New Delhi 110002, India \\ ${ }^{2}$ ITS Paramedical College (Pharmacy), Delhi Meerut Road, Muradnagar, Ghaziabad 201206, India
}

Correspondence should be addressed to Sulekh Chandra, schandra_00@yahoo.com, parmarshikha@yahoo.com

Received 13 May 2008; Revised 1 February 2009; Accepted 6 February 2009

Recommended by Nick Katsaros

A series of metal complexes of $\mathrm{Zn}(\mathrm{II})$ and $\mathrm{Hg}(\mathrm{II})$ having the general composition $\left[\mathrm{M}(\mathrm{L})_{2}\right] \mathrm{X}_{2}$ [where $\mathrm{L}=2$-formylpyridine thiosemicarbazone; $\mathrm{M}=\mathrm{Zn}(\mathrm{II})$ and $\mathrm{Hg}(\mathrm{II}) ; \mathrm{X}=\mathrm{Cl}^{-}, \mathrm{NO}_{3}{ }^{-}$and $1 / 2 \mathrm{SO}_{4}{ }^{2-}$ ] have been prepared and characterized by elemental chemical analysis, molar conductance, and spectral (IR and mass) studies. The IR spectral data suggests the involvement of sulphur and azomethane nitrogen in coordination to the central metal ion. On the basis of spectral studies, a tetrahedral geometry has been assigned for $\mathrm{Zn}$ (II) and $\mathrm{Hg}$ (II) complexes. The free ligand and its metal complexes have been tested in vitro against a number of microorganisms in order to assess their antimicrobial properties.

Copyright ( $) 2009$ Sulekh Chandra et al. This is an open access article distributed under the Creative Commons Attribution License, which permits unrestricted use, distribution, and reproduction in any medium, provided the original work is properly cited.

\section{Introduction}

Thiosemicarbazones are very versatile ligands. They can coordinate to metals as neutral molecules or, after deprotonation, as anionic ligands, and can adopt a variety of different coordination modes [1]. The mono-thiosemicarbazones usually behave as tridentate ligands while the bis-thiosemicarbazones normally bind to the metal center through the two $S$ atoms, the two azomethine nitrogen, and the pyridine nitrogen [2]. Interest in metal complexes with thiosemicarbazones and semicarbazone ligands has been stimulated because biological activities are often enhanced on complexation. Thiosemicarbazones and their metal complexes have received considerable attention because of their antibacterial, antifungal, antitumor, antiamoebic, antimalarial, antiviral, radioprotective, trypanocidal, and anti-inflammatory activities [3-14].

The biological activity is considered to involve three kinds of mechanisms: (i) inhibition of enzyme ribonucleoside diphosphate reductase (essential for DNA synthesis); (ii) creation of lesions in DNA strand by oxidative rupture; (iii) binding to the nitrogen bases of DNA or RNA, hindering or blocking base replication [15].
In view of the above applications, the present work relates to the synthesis, spectroscopic, and antimicrobial studies on $\mathrm{Zn}$ (II) and $\mathrm{Hg}$ (II) complexes of 2-formylpyridine thiosemicarbazone. The ligand used in the study is depicted in Figure 1.

\section{Experimental}

2.1. Materials. All the chemicals used were of Anala R grade and procured from Sigma-Aldrich and Fluka. Metal salts were purchased from E. Merck and used as received.

2.2. Synthesis of Ligand (L). Hot ethanolic solution of thiosemicarbazide $(4.55 \mathrm{~g}, 0.05 \mathrm{~mol})$ and 2-formylpyridine $(4.75 \mathrm{~mL}, 0.05 \mathrm{~mol})$ were mixed slowly with constant stirring. This mixture was refluxed at $70-80^{\circ} \mathrm{C}$ for 2 hours. On cooling, a cream colored compound was precipitated out. It was filtered, washed with cold $\mathrm{EtOH}$, and dried under vacuum over $\mathrm{P}_{4} \mathrm{O}_{10}$ (yield $(65 \%)$, mp $210^{\circ} \mathrm{C}$ ). Elemental chemical analysis data is shown in Table 1.

2.3. Synthesis of Complexes. Hot ethanolic solution $(20 \mathrm{~mL})$ of ligand $(0.02 \mathrm{~mol})$ and hot ethanolic solution $(20 \mathrm{~mL})$ 


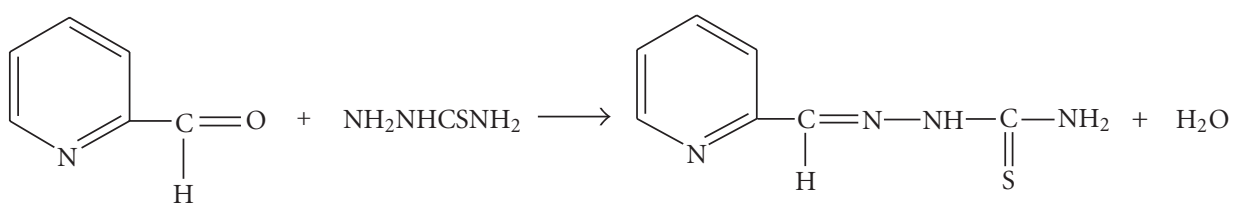

FIgURE 1: Synthesis and structure of ligand.

TABle 1: Analytical data for the ligand and its $\mathrm{Zn}(\mathrm{II})$ and $\mathrm{Hg}(\mathrm{II})$ complexes.

\begin{tabular}{|c|c|c|c|c|c|c|c|c|c|c|}
\hline \multirow{2}{*}{ Compounds } & \multirow{2}{*}{$\begin{array}{l}\text { Molecular } \\
\text { formulae }\end{array}$} & \multirow{2}{*}{$\begin{array}{l}\text { Atomic mass } \\
\text { found (calcd) }\end{array}$} & \multirow{2}{*}{$\begin{array}{l}\text { Yield } \\
(\%)(g)\end{array}$} & \multirow{2}{*}{ Color } & \multirow{2}{*}{$\operatorname{Mp}\left({ }^{\circ} \mathrm{C}\right)$} & \multicolumn{4}{|c|}{ Analysis found (calcd) } & \multirow{2}{*}{$\begin{array}{l}\text { Molar conductance } \\
\left(\Omega^{-1} \mathrm{~cm}^{2} \mathrm{~mol}^{-1}\right)\end{array}$} \\
\hline & & & & & & C & $\mathrm{H}$ & $\mathrm{N}$ & M & \\
\hline \multirow[t]{2}{*}{ Ligand (L) } & $\mathrm{C}_{7} \mathrm{H}_{8} \mathrm{~N}_{4} \mathrm{~S}$ & $179(180)$ & 65 & Shiny & 210 & 46.67 & 4.45 & 31.11 & - & - \\
\hline & & & $(4.97)$ & Cream & & $(46.62)$ & $(4.49)$ & $(31.20)$ & - & \\
\hline \multirow[t]{2}{*}[\mathrm{Zn}(\mathrm{L})_{2}]{$\mathrm{Cl}_{2}$} & $\mathrm{ZnC}_{14} \mathrm{H}_{16} \mathrm{~N}_{8} \mathrm{~S}_{2} \mathrm{Cl}_{2}$ & $496(495)$ & 61 & $\begin{array}{c}\text { Off } \\
\text { white }\end{array}$ & 285 & 33.95 & 3.26 & 22.59 & 13.15 & 122 \\
\hline & & & $(3.01)$ & & & $(33.93)$ & $(3.23)$ & $(22.62)$ & (13.13) & \\
\hline \multirow{2}{*}[\mathrm{Zn}(\mathrm{L})_{2}]{$\left(\mathrm{NO}_{3}\right)_{2}$} & $\mathrm{ZnC}_{14} \mathrm{H}_{16} \mathrm{~N}_{10} \mathrm{~S}_{2} \mathrm{O}_{6}$ & $551(549)$ & 59 & Milky & 212 & 30.58 & 2.96 & 20.43 & 11.85 & 128 \\
\hline & & & $(3.23)$ & Yellow & & $(30.60)$ & $(2.91)$ & $(20.40)$ & $(11.83)$ & \\
\hline \multirow{2}{*}[\mathrm{Zn}(\mathrm{L})_{2}]{$\left(\mathrm{SO}_{4}\right)$} & $\mathrm{ZnC}_{14} \mathrm{H}_{16} \mathrm{~N}_{8} \mathrm{~S}_{3} \mathrm{O}_{4}$ & $520(521)$ & 55 & Yellow & $>350$ & 32.29 & 3.09 & 21.43 & 12.44 & 125 \\
\hline & & & $(2.86)$ & & & $(32.24)$ & (3.07) & $(21.49)$ & (12.47) & \\
\hline \multirow[t]{2}{*}[\mathrm{Hg}(\mathrm{L})_{2}]{$\mathrm{Cl}_{2}$} & $\mathrm{HgC}_{14} \mathrm{H}_{16} \mathrm{~N}_{8} \mathrm{~S}_{2} \mathrm{Cl}_{2}$ & $633(631)$ & 62 & $\begin{array}{c}\text { Off } \\
\text { white }\end{array}$ & 225 & 26.67 & 2.57 & 17.78 & 31.89 & 133 \\
\hline & & & $(3.91)$ & & & $(26.62)$ & $(2.53)$ & $(17.74)$ & $(31.85)$ & \\
\hline \multirow[t]{2}{*}[\mathrm{Hg}(\mathrm{L})_{2}]{$\left(\mathrm{NO}_{3}\right)_{2}$} & $\mathrm{HgC}_{14} \mathrm{H}_{16} \mathrm{~N}_{10} \mathrm{~S}_{2} \mathrm{O}_{6}$ & $687(685)$ & 60 & Dark & 125 & 24.58 & 2.36 & 20.40 & 29.31 & 140 \\
\hline & & & $(4.11)$ & brown & & $(24.52)$ & $(2.33)$ & $(20.43)$ & $(29.34)$ & \\
\hline \multirow{2}{*}[\mathrm{Hg}(\mathrm{L})_{2}]{$\left(\mathrm{SO}_{4}\right)$} & $\mathrm{HgC}_{14} \mathrm{H}_{16} \mathrm{~N}_{8} \mathrm{~S}_{3} \mathrm{O}_{4}$ & $655(657)$ & 60 & Brown & 180 & 25.53 & 2.40 & 17.09 & 30.55 & 138 \\
\hline & & & $(3.94)$ & & & $(25.57)$ & $(2.43)$ & $(17.04)$ & $(30.59)$ & \\
\hline
\end{tabular}

of the corresponding metal salts $(0.01 \mathrm{~mol})$ were mixed together with constant stirring. The mixture was refluxed for 3-4 hours at $70-80^{\circ} \mathrm{C}$. On cooling, colored complexes were precipitated out. They were filtered, washed with $50 \%$ ethanol, and dried under vacuum over $\mathrm{P}_{4} \mathrm{O}_{10}$.

2.4. Analysis. The $\mathrm{C}, \mathrm{H}$, and $\mathrm{N}$ were analyzed on Carlo-Erba 1106 elemental analyzer. The nitrogen content of the complexes was determined using Kjeldahl's method. Zinc and mercury metal ions were determined complexometrically. Molar conductance was measured on the ELICO (CM82T) conductivity bridge. Electronic impact mass spectrum was recorded on JEOL, JMS-DX-303 mass spectrometer. IR spectra $(\mathrm{KBr})$ were recorded on FTIR spectrum BX-II spectrophotometer. The molecular weights of the complexes were determined cryoscopically in benzene.

2.5. Antimicrobial Screening. In vitro antimicrobial screening was performed by the agar disc diffusion method [16, 17]. All the test organisms were obtained from Microbial Type Culture Collection and Gene Bank (MTCC), Institute of Microbial Technology, Chandigarh, India. Nutrient agar growth media was prepared according to the instructions of MTCC. $25 \mathrm{~mL}$ nutrient agar media was poured in each petriplate of $90 \mathrm{~mm}$ diameter. The inoculum was spread on the top of solidified media. Sterile discs of Whatmann no. 1 filter paper having a diameter of $6 \mathrm{~mm}$, impregnated with the test compounds, were placed at four equidistant places on the inoculated petriplates. The zone of inhibition was calculated in millimeters.

2.5.1. Antibacterial Screening. The antibacterial activity of the ligand and its metal complexes were tested against gram-positive (Staphylococcus aureus and Staphylococcus epidermides) and gram-negative (Escherichia coli and Pseudomonas aeruginosa) pathogenic bacteria at a concentration of $100 \mu \mathrm{gdisc}^{-1}$. Nutrient agar media was prepared by using peptone, beef extract, yeast extract, $\mathrm{NaCl}$, agar-agar, and distilled water. Bacterial cultures were adjusted to 0.5 McFarland turbidity standard and inoculated onto the nutrient agar plates [18]. The discs were carefully transferred onto the seeded agar plates. Filter paper disc treated with DMSO served as control and, Amikacin $\left(30 \mu \mathrm{gdisc}^{-1}\right)$ was used as a standard drug. All determinations were made in duplicate for each of the compounds. An average of two independent readings for each compound was recorded. The petriplates were incubated at $37^{\circ} \mathrm{C}$ for 24 hours. The zone of inhibition was calculated.

2.5.2. Antifungal Screening. The antifungal activity of the ligand and its metal complexes were tested against two 


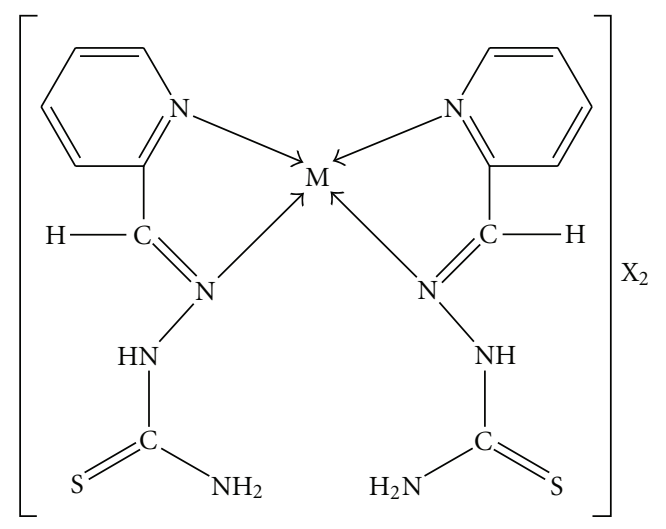

Figure 2: Suggested structure of complex, where $\mathrm{M}=\mathrm{Zn}$ (II) and $\mathrm{Hg}(\mathrm{II})$ and $\mathrm{X}=\mathrm{Cl}^{-}, \mathrm{NO}_{3}{ }^{-}$and $1 / 2 \mathrm{SO}_{4}{ }^{2-}$.

pathogenic fungi, Candida albicans and Aspergillus niger at a concentration of $200 \mu \mathrm{gdisc}^{-1}$ for each. Nystatin was used as standard fungicide, and DMSO served as a means of control. For Candida albicans, nutrient agar media was prepared using yeast extract, peptone, dextrose, agar-agar, and distilled water. Inoculum suspension in normal saline was prepared from fresh, mature (3 to 5 days old) cultures grown on nutrient agar slants. Using spectrophotometry at $530 \mathrm{~nm}$, turbidity was measured and adjusted to match a 0.5 McFarland density standard resulting in an inoculum containing $1 \times 10^{6}$ to $5 \times 10^{6}$ fungal cells $/ \mathrm{mL}$ [19]. This suspension was used to directly inoculate agar plates.

For Aspergillus niger, nutrient agar media was prepared using czapek concentrate $\left(\mathrm{NaNO}_{3}, \mathrm{KCl}, \mathrm{MgSO}_{4} \cdot 7 \mathrm{H}_{2} \mathrm{O}\right.$, $\mathrm{FeSO}_{4} \cdot 7 \mathrm{H}_{2} \mathrm{O}$, and distilled water), $\mathrm{K}_{2} \mathrm{HPO}_{4}$, yeast extract, sucrose, agar-agar, and distilled water. Seven days old colonies were covered with approximately $1 \mathrm{~mL}$ of sterile $0.85 \%$ saline, and the suspensions were made by gently probing the colonies. The resulting mixture of conidia and hyphal fragments was withdrawn and transferred to sterile tube. After heavy particles were allowed to settle for 3 to 5 minutes, the upper homogenous suspensions were collected. The densities of the conidial suspensions were read and adjusted to an optical density (OD) that ranged from 0.09 to

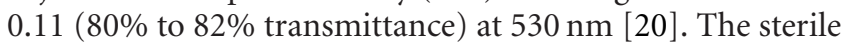
discs impregnated with the test compounds were placed on the already seeded plates at $30^{\circ} \mathrm{C}$ for 48 hours. A clearing zone around the disc indicated the inhibition activity of the test compounds on the pathogenic fungi.

\section{Results and Discussion}

The complexes were synthesized by reacting ligand with the metal ions in $2: 1$ molar ratio in an ethanolic medium. The ligand that behaves as bidentate coordinates through the $\mathrm{N}_{\text {azomethane }}$ and $\mathrm{N}_{\text {pyridine }}$ chelating centers (Figure 2). Elemental analysis of complexes corresponds to the composition as shown in Table 1. All the complexes are found to be soluble in DMSO and DMF, sparingly soluble in water and ethanol, and insoluble in acetone. The molar conductance measurements of the complexes in DMF lies

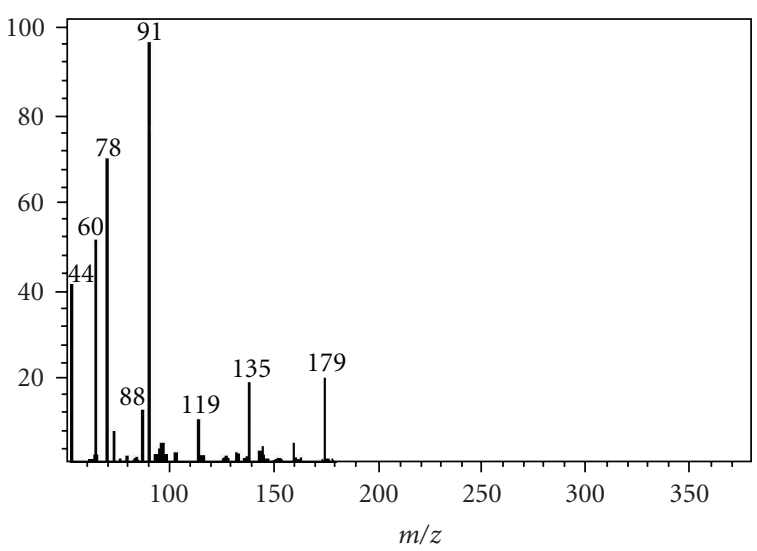

FIGURE 3: Electronic impact mass spectra of ligand (L).

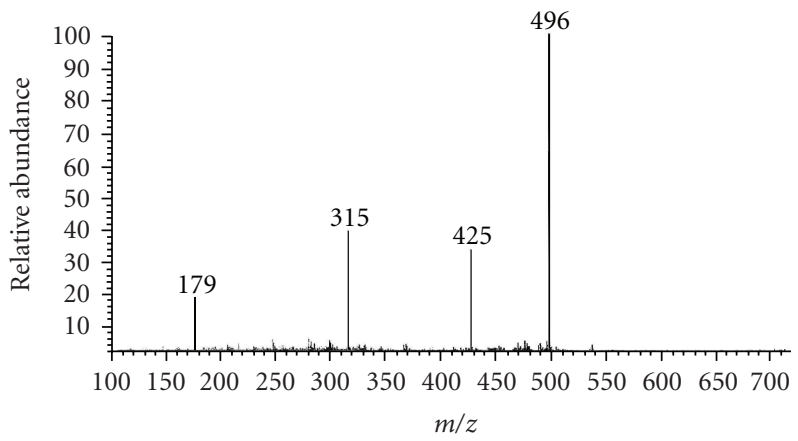

Figure 4: Electronic impact mass spectra of $\left[\mathrm{Zn}(\mathrm{L})_{2}\right] \mathrm{Cl}_{2}$.

in the range of $122-140 \Omega^{-1} \mathrm{~cm}^{2} \mathrm{~mol}^{-1}$, indicating their $1: 2$ electrolytic behavior. Thus, the complexes may be formulated as $\left[\mathrm{M}(\mathrm{L})_{2}\right] \mathrm{X}_{2}$, (where $\mathrm{M}=\mathrm{Zn}(\mathrm{II})$ and $\mathrm{Hg}(\mathrm{II})$; $\mathrm{L}=2$-formylpyridine thiosemicarbazone; $\mathrm{X}=\mathrm{Cl}^{-}, \mathrm{NO}_{3}{ }^{-}$ and $\left.1 / 2 \mathrm{SO}_{4}{ }^{2-}\right)$.

\section{Mass Spectrum}

The electronic impact mass spectrum of the ligand (Figure 3) shows the final peak at $179 \mathrm{amu}\left[\left(\mathrm{C}_{7} \mathrm{H}_{8} \mathrm{~N}_{4} \mathrm{~S}\right)\right.$, calculated atomic mass $180 \mathrm{amu}$ ], and other peaks like 44, 60, 78, 88, 91,119 , and 135 amu may correspond to various fragments. The weak peak described at $135 \mathrm{amu}$ is assigned to the fragment $\left[\mathrm{C}_{6} \mathrm{H}_{8} \mathrm{~N}_{4}\right]^{+}$, corresponding to the loss of CS group. A very weak peak at $119 \mathrm{amu}$ is assigned to the fragment $\left[\mathrm{C}_{6} \mathrm{H}_{6} \mathrm{~N}_{3}\right]^{+}$, corresponding to the loss of $\mathrm{CSNH}_{2}$ group. The most intense peak at 91 corresponds to the fragment $\left[\mathrm{C}_{6} \mathrm{H}_{5} \mathrm{~N}\right]^{+}$. Other peaks at $88,78,60$, and 44 correspond to the fragments $\left[\mathrm{CH}_{3} \mathrm{~N}_{3} \mathrm{~S}\right]^{+},\left[\mathrm{C}_{5} \mathrm{H}_{4} \mathrm{~N}\right]^{+},\left[\mathrm{CSNH}_{2}\right]^{+}$, and $[\mathrm{CS}]^{+}$, respectively.

Complex $\left[\mathrm{Zn}(\mathrm{L})_{2}\right] \mathrm{Cl}_{2}$ shows a single peak at $496 \mathrm{amu}$, which coincides with that of molecular ion. Loss of two chloride ions is in agreement with a peak at $425 \mathrm{amu}$. Loss of one of the ligands is in agreement with a peak at $315 \mathrm{amu}$. A single peak at $179 \mathrm{amu}$ coincides with that of 2-formylpyridine thiosemicarbazone (Figure 4). Complex 
TABLE 2: Important infrared spectral bands $\left(\mathrm{cm}^{-1}\right)$ and their assignments, where $\mathrm{s}=$ strong; $\mathrm{ms}=$ medium strong; $\mathrm{m}=\mathrm{medium}$; $\mathrm{mw}=$ medium weak; $\mathrm{w}=$ weak.

\begin{tabular}{|c|c|c|c|c|c|}
\hline \multirow{2}{*}{ Compounds } & \multicolumn{5}{|c|}{ Assignments } \\
\hline & $\nu(\mathrm{N}-\mathrm{H})$ & $\nu(\mathrm{N}=\mathrm{N})$ & $\nu(\mathrm{C}=\mathrm{N})_{\text {azomethane }}$ & $\nu(\mathrm{C}=\mathrm{N})_{\text {pyridine }}$ & $v(\mathrm{M}-\mathrm{N})$ \\
\hline $\mathrm{C}_{7} \mathrm{H}_{8} \mathrm{~N}_{4} \mathrm{~S}$ ligand (L) & $3267 \mathrm{~s}$ & $1107 \mathrm{~s}$ & $1611 \mathrm{~s}$ & $557 \mathrm{~m}$ & - \\
\hline$\left[\mathrm{Zn}(\mathrm{L})_{2}\right] \mathrm{Cl}_{2}$ & $3275 \mathrm{~s}$ & $1183 \mathrm{~s}$ & $1589 \mathrm{~s}$ & $664 \mathrm{~m}$ & $474 \mathrm{~m}$ \\
\hline$\left[\mathrm{Zn}(\mathrm{L})_{2}\right]\left(\mathrm{NO}_{3}\right)_{2}$ & $3275 \mathrm{~m}$ & $1177 \mathrm{~s}$ & $1588 \mathrm{~m}$ & $661 \mathrm{~m}$ & $478 \mathrm{~m}$ \\
\hline$\left[\mathrm{Zn}(\mathrm{L})_{2}\right]\left(\mathrm{SO}_{4}\right)$ & $3286 \mathrm{~m}$ & $1167 \mathrm{~ms}$ & $1560 \mathrm{~m}$ & $673 \mathrm{~m}$ & $486 \mathrm{mw}$ \\
\hline$\left[\mathrm{Hg}(\mathrm{L})_{2}\right] \mathrm{Cl}_{2}$ & $3292 \mathrm{~ms}$ & $1155 \mathrm{~m}$ & $1594 \mathrm{~s}$ & $626 \mathrm{~m}$ & $460 \mathrm{w}$ \\
\hline$\left[\mathrm{Hg}(\mathrm{L})_{2}\right]\left(\mathrm{NO}_{3}\right)_{2}$ & $3295 \mathrm{~s}$ & $1171 \mathrm{~m}$ & $1551 \mathrm{~m}$ & $621 \mathrm{~m}$ & $459 \mathrm{~m}$ \\
\hline$\left[\mathrm{Hg}(\mathrm{L})_{2}\right]\left(\mathrm{SO}_{4}\right)$ & $3273 \mathrm{~s}$ & $1163 \mathrm{~m}$ & $1599 \mathrm{~ms}$ & $621 \mathrm{~m}$ & $453 \mathrm{w}$ \\
\hline
\end{tabular}

TABLE 3: Antibacterial screening data of the ligand and its $\mathrm{Zn}(\mathrm{II})$ and $\mathrm{Hg}(\mathrm{II})$ complexes.

\begin{tabular}{|c|c|c|c|c|c|}
\hline \multirow{3}{*}{ Compounds } & \multirow{3}{*}{ (Conc.) $\mu \mathrm{g} /$ disc } & \multicolumn{4}{|c|}{ Diameter of zone of inhibition (mm) } \\
\hline & & \multicolumn{2}{|c|}{ Gram positive } & \multicolumn{2}{|c|}{ Gram negative } \\
\hline & & Staphylococcus aureus & Staphylococcus epidermidis & Escherichia coli & Pseudomonas aeruginosa \\
\hline Ligand $\left(\mathrm{C}_{7} \mathrm{H}_{8} \mathrm{~N}_{4} \mathrm{~S}\right)$ & 100 & 20 & 16 & 18 & 08 \\
\hline$\left[\mathrm{Zn}(\mathrm{L})_{2}\right] \mathrm{Cl}_{2}$ & 100 & 10 & 09 & 09 & 10 \\
\hline$\left[\mathrm{Zn}(\mathrm{L})_{2}\right]\left(\mathrm{NO}_{3}\right)_{2}$ & 100 & 12 & 10 & 08 & 08 \\
\hline$\left[\mathrm{Zn}(\mathrm{L})_{2}\right] \mathrm{SO}_{4}$ & 100 & 08 & 09 & 07 & 07 \\
\hline$\left[\mathrm{Hg}(\mathrm{L})_{2}\right] \mathrm{Cl}_{2}$ & 100 & 24 & 20 & 22 & 16 \\
\hline$\left[\mathrm{Hg}(\mathrm{L})_{2}\right]\left(\mathrm{NO}_{3}\right)_{2}$ & 100 & 25 & 18 & 21 & 12 \\
\hline$\left[\mathrm{Hg}(\mathrm{L})_{2}\right] \mathrm{SO}_{4}$ & 100 & 20 & 17 & 19 & 10 \\
\hline Amikacin & 30 & 26 & 22 & 21 & 20 \\
\hline
\end{tabular}

$\left[\mathrm{Zn}(\mathrm{L})_{2}\right]\left(\mathrm{NO}_{3}\right)_{2}$ shows one peak at $551 \mathrm{amu}$, which coincides with that of molecular ion. Loss of one of the ligands is in agreement with a peak at $370 \mathrm{amu}$. $\left[\mathrm{Zn}(\mathrm{L})_{2}\right]\left(\mathrm{SO}_{4}\right)$, $\left[\mathrm{Hg}(\mathrm{L})_{2}\right] \mathrm{Cl}_{2}, \quad\left[\mathrm{Hg}(\mathrm{L})_{2}\right]\left(\mathrm{NO}_{3}\right)_{2}$, and $\left[\mathrm{Hg}(\mathrm{L})_{2}\right]\left(\mathrm{SO}_{4}\right)$ show peaks at 520,633,687, and $655 \mathrm{amu}$, respectively, which are in agreement with their molecular formulae.

\section{Infrared Spectrum}

The assignments of the significant IR spectral bands of ligand and its metal complexes are presented in Table 2. The highest frequency band of the 2-formylpyridine thiosemicarbazone at $3429 \mathrm{~cm}^{-1}$ can be assigned to asymmetric $\nu(\mathrm{N}-\mathrm{H})$ vibration of the terminal $\mathrm{NH}_{2}$ group. The other bands at 3267 and $3164 \mathrm{~cm}^{-1}$ may be due to the symmetric $\nu(\mathrm{N}-\mathrm{H})$ vibrations of the imino and amino groups. A band at $1611 \mathrm{~cm}^{-1}$ in the IR spectra of the ligand is due to $v(\mathrm{C}=\mathrm{N})_{\text {azomethane }}$ group. Coordination of azomethine nitrogen in complexes is suggested by the shift of $v(\mathrm{C}=\mathrm{N})_{\text {azomethane }}$ band to lower frequencies along with the occurrence of $\nu(\mathrm{N}=\mathrm{N})$ band at higher frequency in the IR spectra of complexes compared to the ligand. Coordination of imine nitrogen is also consistent with the presence of a band at $453-486 \mathrm{~cm}^{-1}$, assignable to $v(\mathrm{M}-\mathrm{N})$. Another band at $557 \mathrm{~cm}^{-1}$ in the free ligand is due to $v(\mathrm{C}=\mathrm{N})_{\text {pyridine }}$ group and is also shifted toward higher frequency. This indicates that the nitrogen atom of the pyridine group is also involved in complex formation. The thioamide $v(\mathrm{C}=\mathrm{S})$ band at $776 \mathrm{~cm}^{-1}$ of free ligand is not shifted on complexation which indicates the noninvolvement of sulfur in coordination [21]. The absence of large systemic shift of $v_{\text {as }}\left(\mathrm{NH}_{2}\right)$ and $v_{\text {sym }}\left(\mathrm{NH}_{2}\right)$ modes to lower frequencies indicates no interaction between the terminal amino nitrogen and the metal ions. In each complex, two 2formylpyridine thiosemicarbazone ligands coordinate to the central metal ion through two pyridine $\mathrm{N}$ atoms and two azomethine $\mathrm{N}$ atoms. Thus, it is concluded that the ligand acts as a bidentate chelating agent.

\section{Anions}

The infrared spectra of the nitrate complexes show sharp and strong band at $1384 \mathrm{~cm}^{-1}$, characteristic for uncoordinated nitrate group [22]. IR bands in the region of 1408-1426 and $615-622 \mathrm{~cm}^{-1}$, characteristic of uncoordinated sulfate group, are seen in the infrared spectra of sulfate complexes [23].

\section{Antimicrobial Studies}

Zinc Complexes. Results of bactericidal screening show that the free ligand (L) was much more active than its zinc complexes, while the antifungal results show that all the zinc complexes are more active than the free ligand. The variation in the effectiveness of different compounds against different organisms depends either on the impermeability of the cells of the microbes or the difference in ribosomes of microbial cells [24] 
TABLE 4: Antifungal screening data of the ligand and its $\mathrm{Zn}(\mathrm{II})$ and $\mathrm{Hg}$ (II) complexes.

\begin{tabular}{lccc}
\hline Compounds & Conc. $(\mu \mathrm{g} /$ disc $)$ & \multicolumn{2}{c}{ Diameter of zone of inhibition (mm) } \\
& & Candida albicans & 14 \\
\hline Ligand $\left(\mathrm{C}_{7} \mathrm{H}_{8} \mathrm{~N}_{4} \mathrm{~S}\right)$ & 200 & 15 & 14 \\
{$\left[\mathrm{Zn}(\mathrm{L})_{2}\right] \mathrm{Cl}_{2}$} & 200 & 16 & 12 \\
{$\left[\mathrm{Zn}(\mathrm{L})_{2}\right]\left(\mathrm{NO}_{3}\right)_{2}$} & 200 & 14 & 07 \\
{$\left[\mathrm{Zn}(\mathrm{L})_{2}\right]\left(\mathrm{SO}_{4}\right)$} & 200 & 20 & 22 \\
{$\left[\mathrm{Hg}(\mathrm{L})_{2}\right] \mathrm{Cl}_{2}$} & 200 & 16 & 16 \\
{$\left[\mathrm{Hg}(\mathrm{L})_{2}\right]\left(\mathrm{NO}_{3}\right)_{2}$} & 200 & 12 & 08 \\
{$\left[\mathrm{Hg}(\mathrm{L})_{2}\right]\left(\mathrm{SO}_{4}\right)$} & 200 & 26 & 18 \\
Nystatin & 200 & & \\
\hline
\end{tabular}

Mercury(II) Complexes. The antimicrobial screening data shows that the ligand exhibits antimicrobial properties, and it is important to note that the $\mathrm{Hg}$ (II) metal chelates exhibit more inhibitory effect than the parent ligand. From Table 3, it is clear that the zone of inhibition is much larger for metal chelates against gram-positive (Staphylococcus aureus and Staphylococcus epidermides) and gram-negative (Escherichia coli and Pseudomonas aeruginosa) pathogenic bacteria. The increased activity of metal chelates can be explained on the basis of chelation theory. It is known that the chelation tends to make the ligand act as a more powerful and potent bactericidal agent, thus killing more of the bacteria than the ligand. It is observed that, in a complex, the positive charge of the metal is partially shared with the donor atoms present in the ligand, and there may be $\pi$-electron delocalization over the whole chelating [25]. This increases the lipophilic character of the metal chelate and favors its permeation through the lipoid layer of the bacterial membranes. There are also other factors which increase the activity, namely solubility, conductivity, and bond length between the metal and the ligand.

The result of fungicidal screening (Table 4) shows that $\mathrm{Hg}$ (II) complexes were more active than the free ligand against pathogenic fungi, Candida albicans and Aspergillus niger. The mode of action may involve the formation of a hydrogen bond through the azomethane nitrogen atom with the active centers of the cell constituents, resulting in interference with the normal cell process [24].

\section{Acknowledgments}

The authors are thankful to ITS Paramedical College (Pharmacy) for providing research facilities and ACBR, USIC Delhi University for recording IR and mass spectra.

\section{References}

[1] E. Bermejo, A. Castiñeiras, I. García, and D. X. West, "Spectral and structural studies of mercury(II) complexes of 2-pyridineformamide N(4)-dimethylthiosemicarbazone," Polyhedron, vol. 22, no. 8, pp. 1147-1154, 2003.

[2] J. S. Casas, M. S. García-Tasende, and J. Sordo, "Main group metal complexes of semicarbazones and thiosemicarbazones. A structural review," Coordination Chemistry Reviews, vol. 209, no. 1, pp. 197-261, 2000.
[3] S. Chandra and L. K. Gupta, "Spectroscopic and biological studies on newly synthesized nickel(II) complexes of semicarbazones and thiosemicarbazones," Spectrochimica Acta Part A, vol. 62, no. 4-5, pp. 1089-1094, 2005.

[4] G. Atassi, P. Dumont, and J. C. Harteel, "Potentiation of the antitumour activity of 2-formylpyridine thiosemicarbazone by metal chelation: 2-formylpyridine thiosemicarbazone zinc sulphate (NSC 294721)," European Journal of Cancer, vol. 15, no. 4, pp. 451-459, 1979.

[5] E. W. Ainscough, A. M. Brodie, W. A. Denny, G. J. Finlay, and J. D. Ranford, "Nitrogen, sulfur and oxygen donor adducts with copper(II) complexes of antitumor 2formylpyridinethiosemicarbazone analogs: physicochemical and cytotoxic studies," Journal of Inorganic Biochemistry, vol. 70, no. 3-4, pp. 175-185, 1998.

[6] K. Husain, A. R. Bhat, and A. Azam, "New Pd(II) complexes of the synthesized $1-N$-substituted thiosemicarbazones of 3-indole carboxaldehyde: characterization and antiamoebic assessment against E. histolytica," European Journal of Medicinal Chemistry, vol. 43, no. 9, pp. 2016-2028, 2008.

[7] M. C. Rodríguez-Argüelles, P. Tourón-Touceda, R. Cao, et al., "Complexes of 2-acetyl- $\gamma$-butyrolactone and 2furancarbaldehyde thiosemicarbazones: antibacterial and antifungal activity," Journal of Inorganic Biochemistry, vol. 103, no. 1, pp. 35-42, 2009.

[8] W. Seebacher, R. Brun, and R. Weis, "New 4aminobicyclo[2.2.2] octane derivatives and their activities against Plasmodium falciparum and Trypanosoma $b$. rhodesiense," European Journal of Pharmaceutical Sciences, vol. 21, no. 2-3, pp. 225-233, 2004.

[9] A. Kolocouris, K. Dimas, C. Pannecouque, et al., "New 2-(1-adamantylcarbonyl)pyridine and 1-acetyladamantane thiosemicarbazones-thiocarbonohydrazones: cell growth inhibitory, antiviral and antimicrobial activity evaluation," Bioorganic \& Medicinal Chemistry Letters, vol. 12, no. 5, pp. 723-727, 2002.

[10] G. Aguirre, L. Boiani, H. Cerecetto, et al., "In vitro activity and mechanism of action against the protozoan parasite Trypanosoma cruzi of 5-nitrofuryl containing thiosemicarbazones," Bioorganic \& Medicinal Chemistry, vol. 12, no. 18, pp. 4885-4893, 2004.

[11] X. Du, C. Guo, E. Hansell, et al., "Synthesis and structureactivity relationship study of potent trypanocidal thio semicarbazone inhibitors of the trypanosomal cysteine protease cruzain," Journal of Medicinal Chemistry, vol. 45, no. 13, pp. 2695-2707, 2002.

[12] X. Du, E. Hansell, J. C. Engel, C. R. Caffrey, F. E. Cohen, and J. H. McKerrow, "Aryl ureas represent a new class of 
anti-trypanosomal agents," Chemistry \& Biology, vol. 7, no. 9, pp. 733-742, 2000.

[13] K. S. Abou Melha, "In-vitro antibacterial, antifungal activity of some transition metal complexes of thiosemicarbazone Schiff base (HL) derived from $\mathrm{N}^{4}$ - $\left(7^{\prime}\right.$-chloroquinolin- $4^{\prime}$ ylamino) thiosemicarbazide," Journal of Enzyme Inhibition and Medicinal Chemistry, vol. 23, no. 4, pp. 493-503, 2008.

[14] S. Chandra and U. Kumar, "Spectroscopic characterization of copper(II) complexes of indoxyl N(4)-methyl thiosemicarbazone," Spectrochimica Acta Part A, vol. 60, no. 12, pp. 28252829, 2004.

[15] J. García-Tojal, J. García-Jaca, R. Cortés, T. Rojo, M. K. Urtiaga, and M. I. Arriortua, "Synthesis and spectroscopic properties of two pyridine-2-carbaldehyde thiosemicarbazonecopper(II) compounds: $\left[\mathrm{CuX}_{2}\left(\mathrm{C}_{7} \mathrm{H}_{8} \mathrm{~N}_{4} \mathrm{~S}\right)\right] \cdot \mathrm{H}_{2} \mathrm{O}(\mathrm{X}$ $=\mathrm{Br}, \mathrm{Cl})$. Crystal structure of the bromo complex," Inorganica Chimica Acta, vol. 249, no. 1, pp. 25-32, 1996.

[16] A. W. Bauer, W. M. Kirby, J. C. Sherris, and M. Turck, "Antibiotic susceptibility testing by a standardized single disk method," American Journal of Clinical Pathology, vol. 45, no. 4, pp. 493-496, 1966.

[17] C. Sheikh, M. S. Hossain, M. S. Easmin, M. S. Islam, and M. Rashid, "Evaluation of in vitro antimicrobial and in vivo cytotoxic properties of some novel titanium-based coordination complexes," Biological \& Pharmaceutical Bulletin, vol. 27, no. 5, pp. 710-713, 2004.

[18] J. M. Andrews, "BSAC standardized disc susceptibility testing method (version 4)," Journal of Antimicrobial Chemotherapy, vol. 56, no. 1, pp. 60-76, 2005.

[19] C. R. Sims, V. L. Paetznick, J. R. Rodriguez, E. Chen, and L. Ostrosky-Zeichner, "Correlation between microdilution, Etest, and disk diffusion methods for antifungal susceptibility testing of posaconazole against Candida spp.," Journal of Clinical Microbiology, vol. 44, no. 6, pp. 2105-2108, 2006.

[20] A. Espinel-Ingroff, M. Bartlett, R. Bowden, et al., "Multicenter evaluation of proposed standardized procedure for antifungal susceptibility testing of filamentous fungi," Journal of Clinical Microbiology, vol. 35, no. 1, pp. 139-143, 1997.

[21] S. K. Chattopadhyay, T. Banerjee, P. Roychoudhury, T. C. W. Mak, and S. Ghosh, "Synthesis, characterization and crystal structure analysis of bis (pyridine-2-carbaldehyde thiosemicarbazonato)cobalt(III) thiocyanate monohydrate," Transition Metal Chemistry, vol. 22, no. 3, pp. 216-219, 1997.

[22] S. Chandra and A. Kumar, "Spectral and magnetic studies of $\mathrm{Co}(\mathrm{II})$ complexes with some nitrogen-oxygen and nitrogensulphur donor ligands," Journal of Saudi Chemical Society, vol. 11, no. 2, pp. 299-306, 2007.

[23] K. Nakamoto, Infrared and Raman Spectra of Inorganic and Coordination Compounds, John Wiley \& Sons, New York, NY, USA, 3rd edition, 1978.

[24] Z. H. Abd El-Wahab, M. M. Mashaly, A. A. Salman, B. A. El-Shetary, and A. A. Faheim, "Co(II), $\mathrm{Ce}(\mathrm{III})$ and $\mathrm{UO}_{2}(\mathrm{VI})$ bis-salicylatothiosemicarbazide complexes: binary and ternary complexes, thermal studies and antimicrobial activity," Spectrochimica Acta Part A, vol. 60, no. 12, pp. 2861-2873, 2004.

[25] S. K. Sengupta, O. P. Pandey, B. K. Srivastava, and V. K. Sharma, "Synthesis, structural and biochemical aspects of titanocene and zirconocene chelates of acetylferrocenyl thiosemicarbazones," Transition Metal Chemistry, vol. 23, no. 4, pp. 349-353, 1998. 


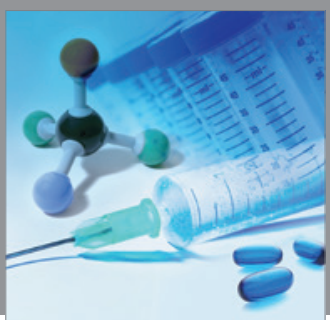

International Journal of

Medicinal Chemistry

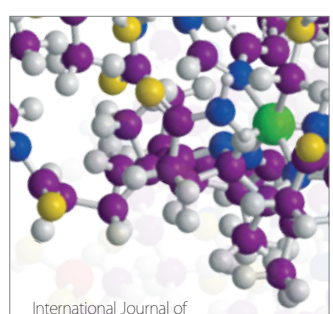

Carbohydrate Chemistry

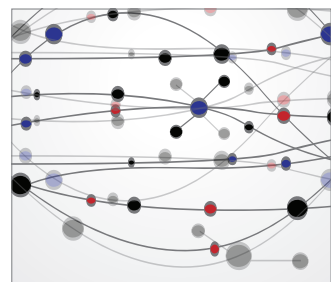

The Scientific World Journal
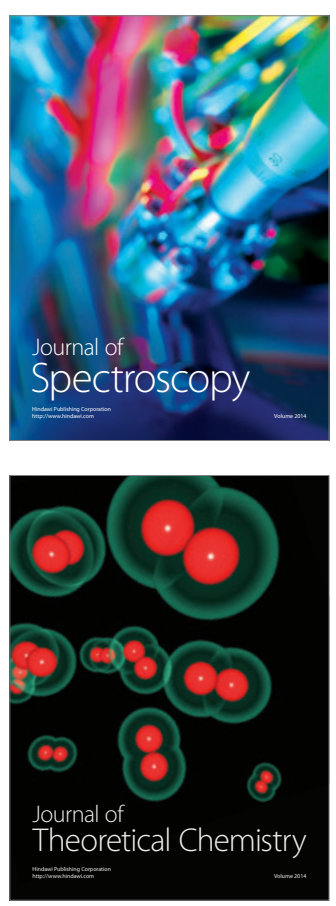
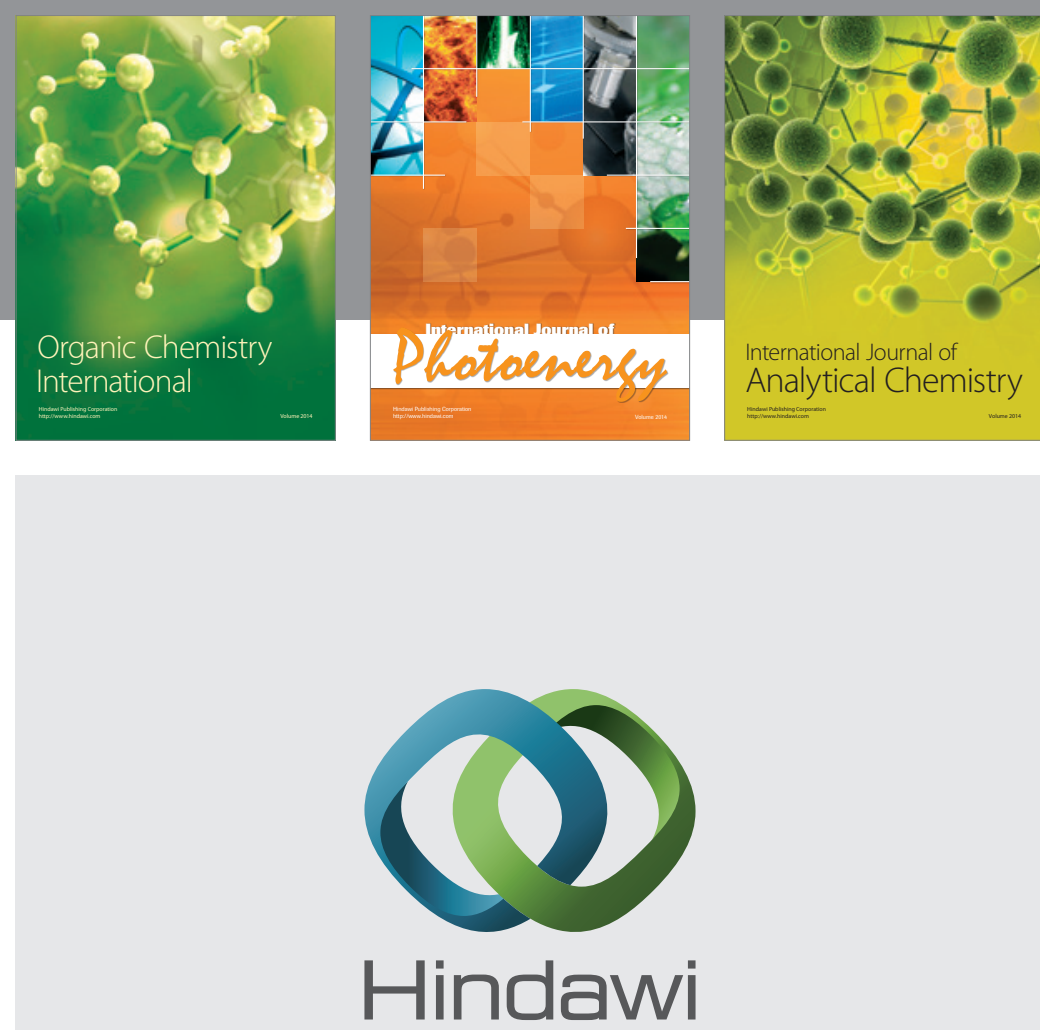

Submit your manuscripts at

http://www.hindawi.com
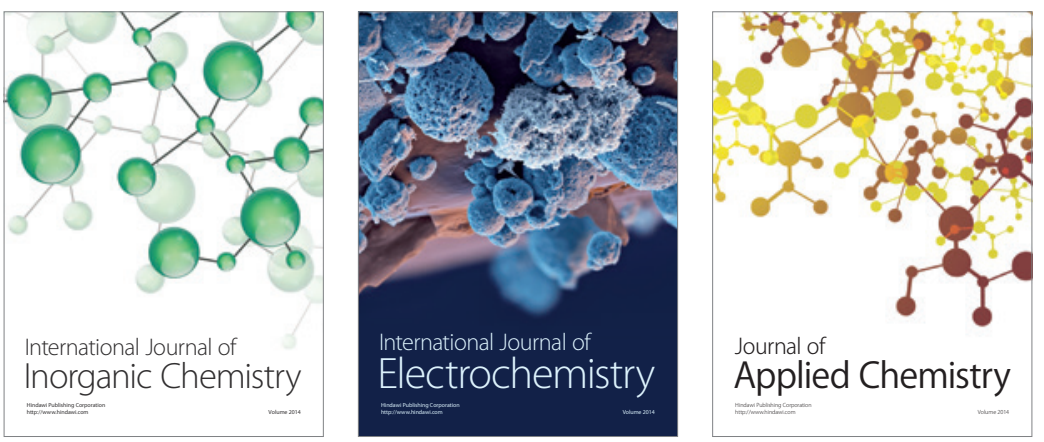

Journal of

Applied Chemistry
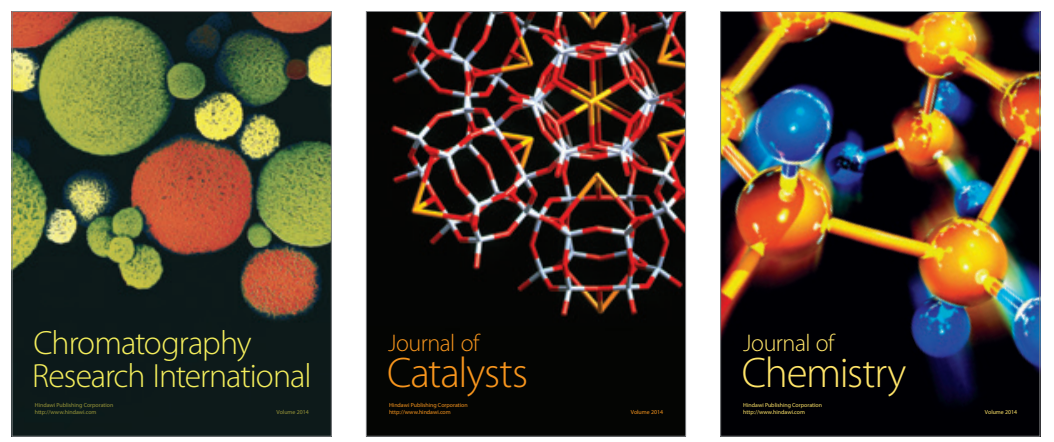
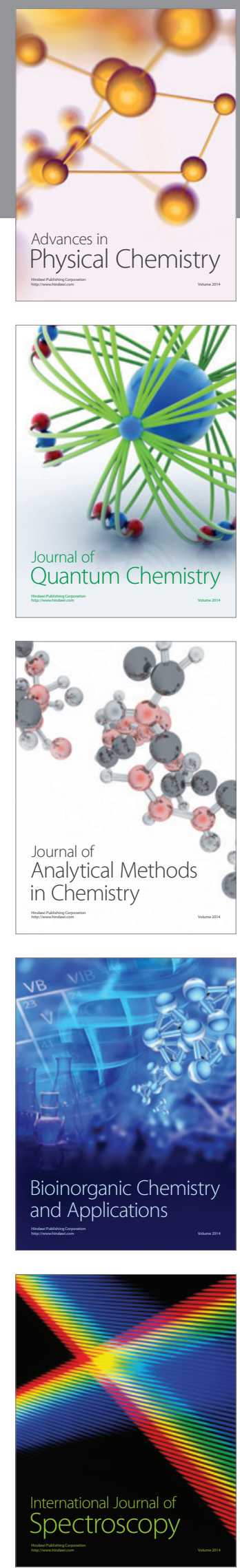